\title{
A correlation of lactate dehydrogenase enzyme levels in pregnancy induced hypertensive disorders with severity of disease, maternal and perinatal outcome
}

\author{
Neha V. Bhave*, Parmanand K. Shah \\ Department of Obstetrics and Gynecology, Seth G. S. Medical College and King Edward Memorial Hospital, Parel, \\ Mumbai, Maharashtra, India
}

Received: 20 August 2017

Revised: 25 August 2017

Accepted: 27 August 2017

*Correspondence:

Dr. Neha V. Bhave,

E-mail: nehabhave17@gmail.com

Copyright: $\odot$ the author(s), publisher and licensee Medip Academy. This is an open-access article distributed under the terms of the Creative Commons Attribution Non-Commercial License, which permits unrestricted non-commercial use, distribution, and reproduction in any medium, provided the original work is properly cited.

\begin{abstract}
Background: A spectrum of hypertensive disorders in pregnancy contribute to maternal and perinatal morbidity and mortality. For prediction and early diagnosis of preeclampsia various biochemical markers, vascular function test and renal markers have been developed. The objective of the study is to measure the lactate dehydrogenase enzyme (LDH) levels in pregnant women with pregnancy induced hypertensive disorders and correlate the levels with the severity of condition, maternal and the perinatal outcome.

Methods: In this prospective observational study, a total of 150 pregnant women were studied. Out of these 150 women, 30 women had normal blood pressure, 30 women had gestational hypertension, 30 women had mild preeclampsia, 30 women had severe preeclampsia and 30 women had eclampsia. The serum LDH levels were measured in third trimester and patients followed up until early postpartum period and babies were followed up till early neonatal period to assess the maternal and neonatal outcomes.

Results: Higher lactate dehydrogenase enzyme (LDH) levels were observed in pregnant women with severe form of hypertensive disorder and those who had a poor maternal and perinatal outcome. This is statistically significant $(\mathrm{p}<0.001)$.

Conclusions: Lactate dehydrogenase enzyme (LDH) level is a useful biochemical marker to assess and predict the severity of disease, maternal and perinatal outcome as higher levels of the enzyme are associated with worsening severity of disease, a poor maternal and perinatal outcome.
\end{abstract}

Keywords: Eclampsia, Gestational hypertension, Lactate dehydrogenase enzyme, Preeclampsia

\section{INTRODUCTION}

Pregnancy causes various cardiovascular and metabolic changes in the mother's body of which change in the blood pressure is considered one significant change. Ten million women develop preeclampsia each year around the world. ${ }^{1}$ Across the world, around 76,000 pregnant women die each year from preeclampsia and related hypertensive disorders. And the number of babies who die from these disorders is thought to be on the order of 500,000 per annum. ${ }^{2}$

Pregnancy induced hypertensive disorders, seen in approximately $10 \%$ of pregnancies, include gestational hypertension, preeclampsia and eclampsia. ${ }^{3}$ In the developing world, severe forms of preeclampsia and eclampsia are more common, ranging from a low of $4 \%$ of all deliveries to as high as $18 \%$ in parts of Africa. ${ }^{4}$ 
Incidence rates for preeclampsia alone - in the United States, Canada and Western Europe, range from 2-5\%, while in Latin America, it is the number one cause of maternal death. ${ }^{4-6}$

The cause of these hypertensive disorders in pregnancy are unknown but basic pathology is considered as the defect in placentation that leads to an inflammatory type of response causing endothelial dysfunction.

Hypertensive disorders in pregnancy lead to a multisystem disorder and thus increase in cellular death. ${ }^{7}$ This cellular death causes the release of the various intracellular enzymes in serum one of which is lactate dehydrogenase enzyme. Thus, this enzyme has been used in this study to assess the severity of the hypertensive disorder and its correlation with maternal and thus the perinatal outcome.

\section{METHODS}

This is a prospective observational study conducted in Department of Obstetrics and Gynecology at Seth G. S. Medical College and K.E.M Hospital, a tertiary care institute for one year. The study protocol was approved by the institute's Ethical committee and an informed consent was taken from each subject prior to participation in this study.

About 150 pregnant women in the third trimester were included in this study. These women were divided into 5 groups with 30 in each group and the groups were as follows:

- Group 1: Healthy Normotensive women (Control group)
- Group 2: Gestational hypertension

- Group 3: Mild Pre-eclampsia

- Group 4: Severe Pre-eclampsia

- Group 5: Eclampsia.

The exclusion criteria included pregnant women with hypertension developing at or less than 20 weeks of gestational age, those who develop gestational diabetes mellitus during this pregnancy, those with preexisting diabetes mellitus type 1 or 2 , thyroid disorder, epilepsy, renal or liver disorder.

Serum LDH levels were obtained from an intravenous sample from these 150 subjects. These subjects were also divided into three sets according to serum LDH levels as follows

- $\quad$ Set A: $<600 \mathrm{IU} / \mathrm{L}$

- Set B: $600-800 \mathrm{IU} / \mathrm{L}$

- $\quad$ Set $\mathrm{C}$ : $>800 \mathrm{IU} / \mathrm{L}$.

All these pregnant women were followed until delivery and early postpartum period and babies were observed till early neonatal period. Maternal and neonatal outcomes were also noted.

\section{RESULTS}

This prospective study was carried in 150 pregnant women in the third trimester. Majority numbers of patients belong to the age group of 20-40 years. On the statistical analysis of the age distribution, the approximate age of normotensive women and women with gestational hypertension was 25 years, with severe preeclampsia was 26years and women with eclampsia was 22 years (Table 1).

Table 1: Mean age in different groups.

\begin{tabular}{|lllllll} 
Groups & Normotensive & $\begin{array}{l}\text { Gestational } \\
\text { hypertension }\end{array}$ & $\begin{array}{l}\text { Mild } \\
\text { preeclampsia }\end{array}$ & $\begin{array}{l}\text { Severe } \\
\text { preeclampsia }\end{array}$ & Eclampsia & $\begin{array}{l}\text { P } \\
\text { value }\end{array}$ \\
$\begin{array}{llllll}\text { Mean age } \pm \text { standard } \\
\text { deviation }\end{array}$ & $25.87 \pm 3.702$ & $25.87 \pm 3.776$ & $24.8 \pm 3.89$ & $26.3 \pm 3.743$ & $22.9 \pm 2.644$ & 0.002
\end{tabular}

On comparison of a particular group with the rest groups, the age distribution of eclamptic patients was statistically proved different from the rest groups (Table 2).

Thus, concluding that eclampsia, a severe form of the disease was seen more commonly in younger age group.

On the comparison between parity in each group, it was observed that pregnancy induced hypertensive disorders were seen more commonly in nulliparous patients than multiparous patients (Table 3, Figure 2). Serum LDH enzyme levels were measured in each group. The mean serum LDH level in normotensive women was 331.20 IU/L and all 30 normotensive cases (100\%) had serum LDH levels <600 IU/L. Out of 30 women with gestational hypertension, 23 cases $(76.66 \%)$ had serum LDH levels $<600$ IU/L and 7 cases $(23.33 \%)$ had serum LDH levels between 600-800IU/L and the mean serum LDH level in these women was 518.17 IU/L.

Out of 30 cases with mild preeclampsia, 18 cases $(60 \%)$ had serum LDH levels <600IU/L and 12 cases $(40 \%)$ had serum LDH levels between 600-800IU/L and the mean serum LDH level in these women with was 571.23 IU/L. 
Table 2: Comparison of different groups for age distribution.

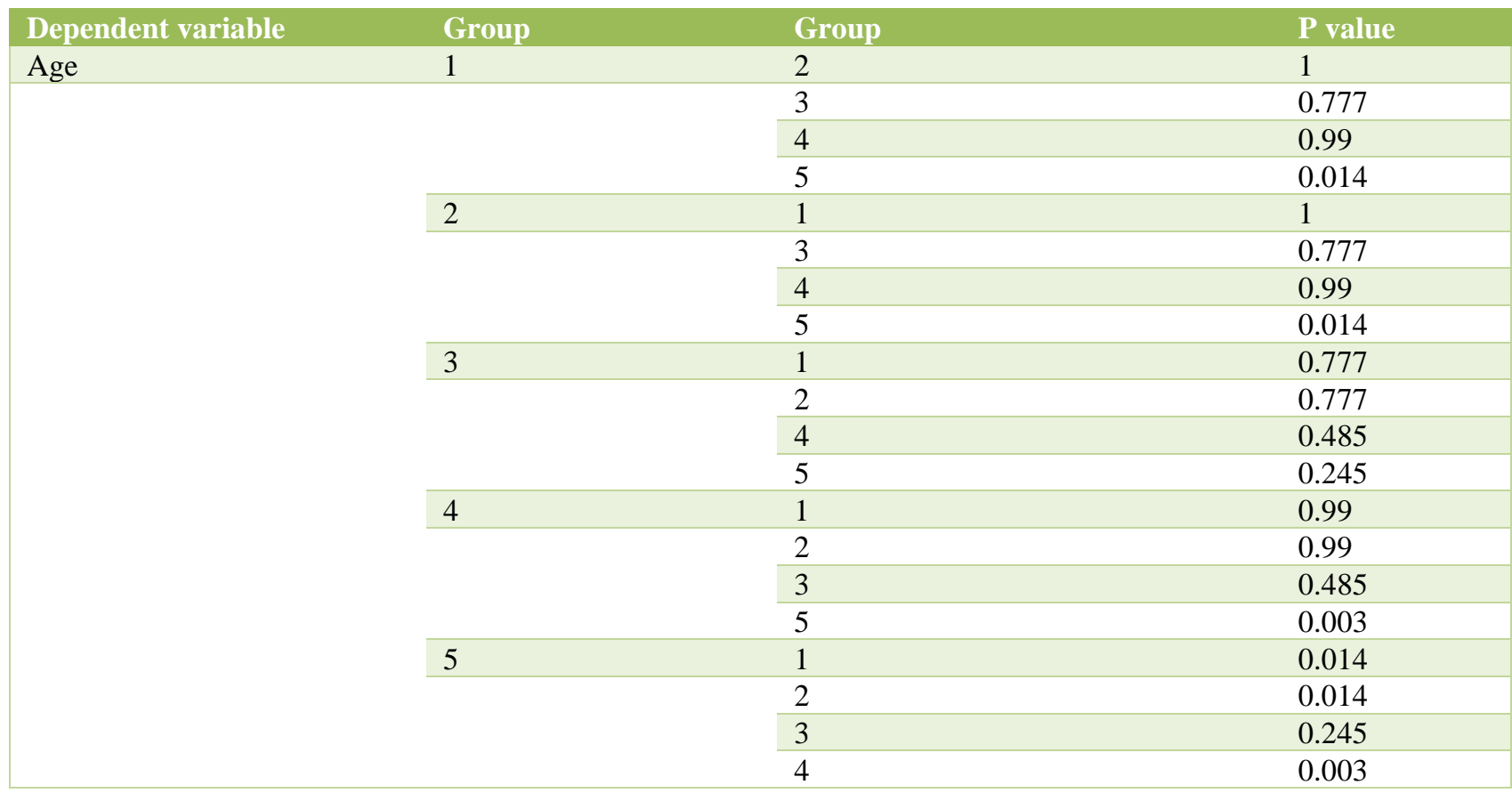

Table 3: Distribution of parity among different groups.

\begin{tabular}{|ll|llll|}
\hline Groups & Normotensive & $\begin{array}{l}\text { Gestational } \\
\text { hypertension }\end{array}$ & $\begin{array}{l}\text { Mild } \\
\text { preeclampsia }\end{array}$ & $\begin{array}{l}\text { Severe } \\
\text { preeclampsia }\end{array}$ & Eclampsia \\
\hline Multiparous & 17 & 10 & 10 & 15 & 7 \\
\hline Nulliparous & 13 & 20 & 20 & 15 & 23 \\
\hline
\end{tabular}

Table 4: Mean serum LDH levels in different groups.

\begin{tabular}{|c|c|c|c|c|c|c|}
\hline Groups & Normotensive & $\begin{array}{l}\text { Gestational } \\
\text { hypertension }\end{array}$ & $\begin{array}{l}\text { Mild } \\
\text { preeclampsia }\end{array}$ & $\begin{array}{l}\text { Severe } \\
\text { preeclampsia }\end{array}$ & Eclampsia & $\begin{array}{l}\mathbf{P} \\
\text { value }\end{array}$ \\
\hline $\begin{array}{l}\text { Mean serum } \\
\text { LDH levels } \pm \\
\text { standard } \\
\text { deviation }\end{array}$ & $331.20 \pm 79.875$ & $518.17 \pm 141.147$ & $571.03 \pm 121.505$ & $1135.5 \pm 1187.701$ & $1163.83 \pm 748.355$ & $<0.001$ \\
\hline
\end{tabular}

Table 5: Association of systolic blood pressure with serum LDH level.

\begin{tabular}{|c|c|c|c|c|c|c|}
\hline & & & Systolic & essure & & Tatal \\
\hline & & & $<140$ & $140-160$ & $>160$ & 10tal \\
\hline & $<600$ & Count & 39 & 38 & 0 & 77 \\
\hline & & $\%$ within LDH & $50.6 \%$ & $49.4 \%$ & $0.0 \%$ & $100.0 \%$ \\
\hline LDH & 600800 & Count & 1 & 30 & 1 & 32 \\
\hline (IU/L) & $000-800$ & $\%$ within LDH & $3.1 \%$ & $93.8 \%$ & $3.1 \%$ & $100.0 \%$ \\
\hline & $>800$ & Count & 1 & 5 & 35 & 41 \\
\hline & & \% within LDH & $2.44 \%$ & $12.20 \%$ & $85.36 \%$ & $100.0 \%$ \\
\hline Total & & Count & 41 & 73 & 36 & 150 \\
\hline & & $\%$ within LDH & $27.33 \%$ & $48.67 \%$ & $24 \%$ & $100.0 \%$ \\
\hline
\end{tabular}

Out of 30 women with severe preeclampsia, 6 cases (20\%) had serum LDH levels < 600 IU/L, 7 cases
(23.33\%) had serum LDH levels between 600-800IU/L and 17 cases $(56.66 \%)$ had serum LDH levels $>800$ IU/L. The mean serum LDH level in women with severe 
preeclampsia was $1135.5 \mathrm{IU} / \mathrm{L}$. Out of 30 cases with eclampsia, no cases had serum LDH levels < $600 \mathrm{IU} / \mathrm{L}$, 10 cases $(33.33 \%)$ had serum LDH levels between 600 $800 \mathrm{IU} / \mathrm{L}$ and 20 cases $(66.66 \%)$ had serum LDH levels $>800 \mathrm{IU} / \mathrm{L}$. The mean serum LDH level in women with eclampsia was $1163.83 \mathrm{IU} / \mathrm{L}$. On statistical analysis, it is clearly observed that increase in serum LDH levels were seen with increasing severity of the condition $(\mathrm{P}<0.001)$ (Table 4).

The systolic blood pressure (SBP) and diastolic blood pressure (DBP) were studied in three sets divided on the basis of serum LDH levels. Out of 77 cases with serum LDH levels <600IU/L, 39 cases $(50.6 \%)$ had SBP < 140 $\mathrm{mm}$ of $\mathrm{Hg}$ and 38 cases (49.4\%) had SBP between 140 $160 \mathrm{~mm}$ of $\mathrm{Hg}$ while 30 cases $(39 \%)$ had DBP $<90 \mathrm{~mm}$ of $\mathrm{Hg}$ and 47 cases (61\%) had DBP between $90-110 \mathrm{~mm}$ of $\mathrm{Hg}$. Out of 32 cases with serum LDH levels between 600IU/L- 800IU/L, 30 cases $(93.8 \%$ ) had SBP between $140-160 \mathrm{~mm}$ of $\mathrm{Hg}$ and out of remaining 2 cases, one case $(3.1 \%)$ had SBP $<140 \mathrm{~mm}$ of $\mathrm{Hg}$ and the other case (3.1\%) had SBP $>160 \mathrm{~mm}$ of $\mathrm{Hg}$ while all 32 cases (100\%) had DBP between $90-110 \mathrm{~mm}$ of $\mathrm{Hg}$. Similarly, out of 41 cases with serum LDH levels > 800 IU/L, 1 case $(2.44 \%)$ had SBP $<140 \mathrm{~mm}$ of $\mathrm{Hg}, 5$ cases $(12.2 \%)$ had SBP between $140-160 \mathrm{~mm}$ of $\mathrm{Hg}$ and 35 cases $(85.36 \%)$ had SBP $>160 \mathrm{~mm}$ of $\mathrm{Hg}$ while 10 cases $(24.39 \%)$ had DBP between $90-110 \mathrm{~mm}$ of $\mathrm{Hg}$ and 31 cases $(75.61 \%)$ had DBP $>110 \mathrm{~mm}$ of $\mathrm{Hg}$. Thus, on statistical analysis, it was proved that raised blood pressure was seen in patients with high serum LDH levels $(\mathrm{P}<0.001)$ (Table 5 and 6).

Table 6: Association of diastolic blood pressure with serum LDH level.

\begin{tabular}{|c|c|c|c|c|c|c|}
\hline & & & \multicolumn{3}{|c|}{ Diastolic blood pressure } & \multirow[b]{2}{*}{ Total } \\
\hline & & & $<90$ & $90-<110$ & $>110$ & \\
\hline \multirow{6}{*}{$\begin{array}{l}\text { LDH } \\
(\mathrm{IU} / \mathrm{L})\end{array}$} & $<600$ & Count & 30 & 47 & 0 & 77 \\
\hline & & $\%$ within LDH & $39.0 \%$ & $61.0 \%$ & $0.0 \%$ & $100.0 \%$ \\
\hline & & Count & 0 & 32 & 0 & 32 \\
\hline & $600-800$ & $\%$ within LDH & $0.0 \%$ & $100.0 \%$ & $0.0 \%$ & $100.0 \%$ \\
\hline & $>800$ & Count & 0 & 10 & 31 & 41 \\
\hline & & $\%$ within LDH & $0.0 \%$ & $24.39 \%$ & $75.61 \%$ & $100.0 \%$ \\
\hline \multirow[t]{2}{*}{ Total } & & Count & 30 & 89 & 31 & 150 \\
\hline & & $\%$ within LDH & $20.0 \%$ & $59.33 \%$ & $20.67 \%$ & $100.0 \%$ \\
\hline
\end{tabular}

Depending on the division of cases on the basis of serum LDH levels, the mean gestational age and birth weight of the baby at the time of delivery were calculated. The mean gestational age and birth weight of the baby in women with serum LDH levels <600 IU/L was 37.80 and $2.621 \mathrm{~kg}$ respectively. The set of cases with serum LDH levels between 600-800 IU/L, the mean gestational age and birth weight of the baby was 36.67 and $2.035 \mathrm{~kg}$ respectively. Similarly, cases with serum LDH levels $>800 \mathrm{IU} / \mathrm{L}$, the mean gestational age and birth weight of the baby was 33.74 and $1.610 \mathrm{~kg}$ respectively.

On statistical analysis, it was proved that chances of premature delivery and low birth weight were high in women with raised serum LDH levels $(\mathrm{P}<0.001)$ (Table $7)$, thus affecting the perinatal outcome.

Table 7: Mean gestational age and mean birth weight in different sets divided on basis of serum LDH levels.

\begin{tabular}{|lllll|}
\hline Serum LDH (IU/L) & $<600$ & $600-800$ & $>800$ & \\
\hline Number of case & 77 & 32 & 41 & P value \\
\hline Mean gestational age (in weeks) \pm Standard deviation & $37.806 \pm 2.465$ & $36.671 \pm 3.301$ & $33.743 \pm 3.244$ & $<0.001$ \\
\hline Mean Birth weight \pm Standard deviation & $2.621 \pm 0.567$ & $2.035 \pm 0.740$ & $1.61 \pm 0.639$ & $<0.001$ \\
\hline
\end{tabular}

Table 8: Mean APGAR score at 1 minute and 5 minutes in different sets.

\begin{tabular}{|c|c|c|c|c|}
\hline Serum LDH (IU/L) & $<600$ & $600-800$ & $>800$ & \\
\hline Number of case & 77 & 32 & 41 & $P$ value \\
\hline APGAR at $1 \min \pm$ Standard deviation & $8.29 \pm 2.299$ & $8.09 \pm 2.438$ & $5.22 \pm 4.162$ & $<0.001$ \\
\hline APGAR at $5 \min \pm$ Standard deviation & $8.45 \pm 2.075$ & $8.41 \pm 2.212$ & $5.59 \pm 4.313$ & \\
\hline
\end{tabular}


To study the perinatal outcome, APGAR scores at 1 minute and 5 minutes were also studied in three sets divided on basis of serum LDH levels. Those cases with serum LDH levels <600 IU/L had APGAR scores at 1 minute and 5 minutes as 8.29 and 8.45 respectively. Those cases with serum LDH levels between 600-800 IU/L had APGAR scores at 1 minute and 5 minutes as 8.09 and 8.41 respectively. Similarly, those cases with serum LDH levels $>800 \mathrm{IU} / \mathrm{L}$ had APGAR scores at 1 minute and 5 minutes as 5.22 and 5.59 respectively. Thus, patients with raised serum LDH levels have poor APGAR score was proved statistically significant ( $P$ $<0.001)$ (Table 8).

Similarly, neonatal complications in the early neonatal period due to prematurity, intrauterine growth restriction etc. were studied along with neonatal deaths and still birth rate to study the perinatal outcome. Out of 77 cases having serum LDH levels $<600$ IU/L, 7 cases $(9.1 \%)$ had developed neonatal complications, one case had neonatal death $(1.3 \%)$ and 4 cases had still births $(5.2 \%)$. Thus, out of 77 cases, there were 5 perinatal deaths $(6.49 \%)$. Those 32 cases with serum LDH levels between 600-800 IU/L, 22 cases $(68.8 \%)$ had developed neonatal complications, one case had neonatal death $(3.1 \%)$ and there 2 cases had still births $(5.2 \%)$. Thus, there were 3 perinatal deaths $(9.37 \%)$ in cases with serum LDH levels between 600 $800 \mathrm{IU} / \mathrm{L}$. Out of 41 cases with serum LDH levels $>800$ IU/L, 32 cases $(78 \%)$ had developed neonatal complications, 6 cases $(14.6 \%)$ had neonatal death and 13 cases $(31.7 \%)$ had still birth. Thus, there were 19 perinatal deaths $(46.34 \%)$ in cases with serum LDH levels >800 IU/L. Hence proved that neonatal complications, neonatal deaths, still births and perinatal deaths were more commonly seen in those with raised serum LDH levels ( $\mathrm{P}<0.001)$ (Table 9).

Table 9: Association of neonatal complications, neonatal death and still birth with serum LDH levels.

\begin{tabular}{|llllr|}
\hline Serum LDH (IU/L) & $<600$ & $600-800$ & $>800$ & P value \\
\hline Number of case & 77 & 32 & 41 & $<0.001$ \\
\hline Cases with Neonatal complications & $7(9.1 \%)$ & $22(68.8 \%)$ & $32(78 \%)$ & 0.007 \\
\hline Neonatal deaths & $1(1.3 \%)$ & $1(3.1 \%)$ & $6(14.6 \%)$ & $<0.001$ \\
\hline still births & $4(5.2 \%)$ & $2(6.2 \%)$ & $13(31.7 \%)$ & $<0.001$ \\
\hline Perinatal death & $5(6.49 \%)$ & $3(9.37 \%)$ & $19(46.34 \%)$ & \\
\hline
\end{tabular}

Table 10: Association of maternal complications with serum LDH levels.

\begin{tabular}{|lllll|}
\hline Serum LDH $($ IU/L) & $<600$ & $600-800$ & $>800$ & P value \\
\hline Number of case & 77 & 32 & 41 & $<0.001$ \\
\hline Maternal complications & $5(6.5 \%)$ & $7(21.9 \%)$ & $22(53.66 \%)$ & \\
\hline
\end{tabular}

Maternal complications seen in pregnancy induced hypertensive disorders like HELLP syndrome, disseminated intravascular coagulation (DIC), Abruptio placentae, acute renal injury or failure, pulmonary edema, posterior reversible encephalopathy syndrome etc. were observed and studied. Out of 77 cases having serum LDH levels $<600 \mathrm{IU} / \mathrm{L}, 5$ cases $(6.5 \%)$ developed maternal complications. Out of 32 cases with serum LDH levels between 600-800 IU/L, 7 cases $(21.9 \%$ ) developed maternal complications. Similarly, out of 41 cases with serum LDH levels >800 IU/L, 23 cases (53.66\%) developed maternal complications. Thus, increase in serum LDH levels are associated with poor maternal outcome was statistically proven $(\mathrm{P}<0.001)$ (Table 10 , Figure 9).

\section{DISCUSSION}

Even today the leading most cause of maternal and neonatal morbidity and mortality in obstetrics is pregnancy induced hypertensive disorders. In spite of being the commonest, the exact etiology of these hypertensive disorders is unknown. There are many theories proposed to explain etiology of preeclampsia but the most accepted theory states that there is an incomplete trophoblastic invasion of uterine arteries causing placental ischemia which results in the release of many anti-angiogenic proteins from placenta causing endothelial dysfunction. ${ }^{8-12}$ This finally results in hypertension, increase in vascular permeability, activation of coagulation cascade and damage to renal filtering mechanisms causing new onset proteinuria.

These changes will cause an increase in serious maternal and fetal risk. Even today the major complications in pregnancy arise due to late detection of these hypertensive disorders or worsening of a milder form of hypertension to severe form.

Currently, many advances in treatment to reduce the impact of these hypertensive disorders have been made, prevention of these disorders with a reliable screening tool still remain to be a constant challenge to the obstetrician. Thus, there appears a need to have a marker 
to predict the severity of the disease that shall be studied in this study.

In this study, we have studied LDH levels in pregnancy and its efficacy in correlation with severity of hypertensive disorders, maternal and neonatal outcome. In our study, the majority of cases belong to a younger age group and are more commonly seen in nulliparous women. Similar findings were also observed by Jaiswar et al, where majority belonged to age group of 20-30 years and commonly seen in nulliparous women. ${ }^{13}$ Our study also proved that eclampsia was more common at an early age which is also proved by Fong et al, which states that eclampsia has a bimodal distribution which peaks in youngest and oldest age group. ${ }^{14}$

Jaiswar et al, observed the mean LDH level in control was $278.33 \pm 119.25 \mathrm{IU} / \mathrm{L}$, in mild preeclampsia was $400.45 \pm 145.21 \mathrm{IU} / \mathrm{L}$, severe preeclampsia was $646.95 \pm 401.64 \mathrm{IU} / \mathrm{L}$ and in eclampsia was $1648.10 \pm 190.29 \mathrm{IU} / \mathrm{L}$, thus establishing a significant association of increasing LDH levels with increasing severity of the condition $(\mathrm{P}<0.001) .{ }^{13}$ Similar result was also observed in our study $(\mathrm{P}<0.001)$. Qulban et al, study demonstrated significant association of $\mathrm{LDH}$ with increasing severity of preeclampsia $(\mathrm{P}<0.001) .{ }^{15}$

The systolic and diastolic blood pressures were significantly higher in patients with rising $\mathrm{LDH}$ levels. This was also observed by Jaiswar et al, study and Qulban et al, study (P <0.001). ${ }^{13,15}$

The mean gestational age and the birth weight of infant at time of delivery was significantly less in patients with higher levels of serum LDH $(\mathrm{P}<0.001)$. Jaiswar et al, showed similar results of low gestational age $(\mathrm{P}=0.25)$ and low birth weight $(\mathrm{P}=0.019)$ with rising levels of serum LDH. He et al, study also proved that serum $\mathrm{LDH}$ were significantly higher with babies born between the gestational period of 24-29 weeks versus 30-35 weeks versus $36-40$ weeks. ${ }^{13,16}$ It also proved that low birth weights were seen in patients with higher serum LDH. Qulban et al, on contrary did not show any significant association between the low birth weight of infant and raised serum LDH levels. ${ }^{15}$

A significant association between falling APGAR scores at 1 minute and 5 minutes with rising serum LDH levels was demonstrated in our study $(\mathrm{P}<0.001$ at 1 minute and 5 minutes) and Jaiswar et al, study $(\mathrm{P}<0.001$ at 1 minute and $\mathrm{P}=0.001$ at 5 minutes). ${ }^{13}$

The effect on perinatal outcome was also studied in Jaiswar et al, study demonstrating a significant increase in neonatal complications $(\mathrm{P}=0.003)$, still births $(\mathrm{P}<0.001)$ and perinatal deaths $(\mathrm{P}=0.003)$ with increasing serum LDH levels. ${ }^{13}$ In our study, similar results were observed showing a significant increase in neonatal complications $(\mathrm{P}<0.001)$, still births $(\mathrm{P}<0.001)$, neonatal deaths $(\mathrm{P}=0.007)$ and perinatal death $(\mathrm{P}<0.001)$.
In our study, it was observed that there was an increase in maternal complications like renal failure, abruptio placentae, HELLP syndrome, pulmonary edema, neurological complications etc. with the increase in serum LDH levels $(\mathrm{P}<0.001)$. Similar results were also obtained from Jaiswar et al, study. Qulban et al, also proved that severe preeclampsia patients with serum LDH levels >800 IU/L showed a significant increase in maternal complications. ${ }^{13,15}$

Thus, it is proved that serum LDH levels show significant correlation with increasing severity of hypertensive disorders, maternal and perinatal outcome.

\section{Funding: No funding sources}

Conflict of interest: None declared

Ethical approval: The study was approved by the Institutional Ethics Committee

\section{REFERENCES}

1. Preeclampsia Foundation. Preeclampsia and Maternal Mortality: a Global Burden, 2013. Available at https://www.preeclampsia.org/healthinformation/149-advocacy-awareness/332preeclampsia-and-maternal-mortality-a-globalburden. Accessed 01 May 2013.

2. Kuklina EV, Ayala C, Callaghan WM. Hypertensive disorders and severe obstetric morbidity in the United States. Obstet Gynecol. 2009;113:1299-306.

3. Fabry IG, Richart T, Chengz X, Van Bortel LM, Staessen JA. Diagnosis and treatment of hypertensive disorders during pregnancy. Acta Clin Belg. 2010;65(4):229-36.

4. Villar J, Say L, Gulmezoglu AM, Marialdi M, Lindheimer MD, Betran AP, et al. Pre-Eclampsia Eclampsia: A Health Problem for 2000 Years. In Preeclampsia, Critchly, H., MacLean, A., Poston, L. and Walker, J., Eds., Preeclampsia, RCOG Press, London; 2003:189-207.

5. Ronsmans C, Graham WJ, Phill D. On behalf of the Lancet Maternal Survival Series steering group. Maternal mortality; who, when, where and why. Lancet. 2006;368(9542):1189-2000.

6. Preeclampsia Foundation, Preeclampsia: A Decade of Perspective, Building a Global Call to Action., Melbourne, Florida; 2010.

7. Davison JM, Homuth V, Jeyabalan A. New aspects in pathophysiology of preeclampsia. J Am Soc Nephrol. 2004;15(9):2440-8.

8. Fisher SJ, Roberts JM. Defects in placentation and placental perfusion. In: Linhheimer MD, Roberts JM, Cunningham FG, eds. Chesley's Hypertensive Disorders in Pregnancy. 2nd ed. Stanford, CT: Appleton and Lange; 1999:377-394.

9. August P, Lindheimer MD. Pathophysiology of preeclampsia In: Laragh JL, Brenner BM, eds. Hypertension. 2nd. New York, NY: Raven Press; 1995:2407-2426. 
10. Hanretty KP, Whittle MJ, Rubin PC. Doppler uteroplacental waveforms in pregnancy-induced hypertension: a re-appraisal. Lancet. 1998;1:850-2.

11. Roberts JM. Endothelial dysfunction in preeclampsia. Semin Reprod Endocrinol. 1998;16:515 .

12. Taylor RN, Roberts JM. Hypertensive Disorders in Pregnancy 2nded. Stanford, CT: Appleton and Lange; 1999:395-429.

13. Jaiswar SP, Gupta A, Rekha S. Lactic Dehydrogenase: a biochemical marker for preeclampsia and eclampsia. J Obstet Gynecol India. 2011;61(6):645-8.

14. Fong A, Chau CT, Pan D. Clinical morbidities, trends, and demographics of eclampsia: a populationbased study. Am J Obstet Gynecol. 2013;209:229.e17.

15. Qublan HS, Ammarin V, Bataineh O, Al-Shraideh Z, Tahat Y, Awamleh I, et al. Lactic dehydrogenase as a biochemical marker of adverse pregnancy outcome in severe preeclampsia. Med Sci Monit. 2005;11(8):CR393-7.

16. Shu He, Bremme K, Kallner A. Increased concentrations of lactate dehydrogenase in pregnancy with preeclampsia: a predictor for birth of small-for-gestational-age infants. Gynecol Obstet Invest. 1995;39:234-8.

Cite this article as: Bhave NV, Shah PK. A correlation of lactate dehydrogenase enzyme levels in pregnancy induced hypertensive disorders with severity of disease, maternal and perinatal outcome. Int J Reprod Contracept Obstet Gynecol 2017;6: 4302-8. 